\title{
DURING A CRISIS CAUSED BY A PANDEMIC, IT IS BEST TO INVEST IN GREEN ENERGY
}

\author{
Marija Mihajlović1 ${ }^{\text {, Ljiljana Stošić Mihajlović }}{ }^{\text {, Svetlana Trajković }}{ }^{3}$ \\ ${ }^{1}$ Faculty of Civil Engineering and Architecture, University of Nis, Serbia \\ ${ }^{2,3}$ Academy of Technical and Educational Vocational Studies in Nis, Serbia \\ mmihajlovic1251997@gmail.com, ljiljana.stosic.mihajlovic@akademijanis.edu.rs \\ svetlana.trajkovic@akademijanis.edu.rs
}

Original Scientific Paper
10.5937/jouproman9-31416

\begin{abstract}
Numerous analyzes show that various factors, including mass vaccination and better virus control, have helped to change policy of job restraint and closure, especially in the SME sector. The governments of almost all countries have recognized that geographically targeted and sectorspecific measures are more acceptable to the people and thus reduce the negative economic consequences of a pandemic. However, the fact is that the health risks are still very pronounced, so it is necessary to establish a balance between public health measures against the virus and measures to support workers and companies affected by the consequences of the pandemic. The question is: where to invest during the pandemic, and especially after, when the pandemic passes? In this paper, we will talk about the measures of the state to help the economy, now that it is the most difficult. In particular, we will talk about sectors that have a future, and are related to the energy sector (especially RES), economy and environment
\end{abstract}

Key words: investing, state incentives, solar panels

\section{INTRODUCTION}

In the last five years before the corona, the Serbian economy grew at an average rate of 1.8 to $4.4 \%$ per year and every year.

The growth was increasing. In 2020, corona brought Serbia a drop in economic activity of about $1.5 \%$, but that is an excellent result in relation to many of the European economies listed above, which fell by more than $10 \%$. Already for this 2021, it is estimated that Serbia expects strong growth of at least $6 \%$. The fastest growing sector in the future is the energy sector and investments in renewable energy sources.

\section{CONSEQUENCES OF THE COVID- 19 CRISIS IN EUROPE AND SERBIA}

Data from the European Bureau of Statistics (Eurostat) show that the second quarter (April, May and June) of this year saw the largest decline in gross domestic product (GDP) on the European continent since 1995. According to officially available Eurostat data from the beginning of September, the fall in GDP in the second quarter, which is still marked by measures to combat the corona virus pandemic, in $27 \mathrm{EU}$ countries is $11.4 \%$, while in the first quarter (January, February and March) ) this decline was $3.3 \%$. PROFIMEDIA 
This is by far the sharpest decline since 1995. Among the Member States for which data are available for the second quarter of this year, the sharpest decline in the second quarter was recorded in Spain $(-18.5 \%)$ compared to the previous quarter, followed by Croatia $(-14.9 \%)$, Hungary $(-14,5 \%)$, Greece $(-14.0 \%)$, Portugal $(-13.9 \%)$ and France $(-13.8 \%)$. It is followed by Italy with 12.4\%, Romania with $12.1 \%$, Belgium 12\%, Cyprus and Malta 11.8\%, Austria 10.2\%, Bulgaria 10\%, Germany $9.8 \%$.

The smallest decline in GDP was recorded in Finland $(-4.5 \%)$, Lithuania $(-5.5 \%)$ and Estonia $(-5.6 \%)$, followed by Ireland ($6.1 \%)$, Latvia $(-6,5 \%)$ and Denmark (6.9\%) (Eurostat data).

Compared to the second quarter of last year, GDP in the EU fell by $14.4 \%$ in the second quarter of this year.

According to the same source, during the second quarter of 2020, final consumption expenditure of households decreased by $12 \%$, gross fixed capital formation by $15.4 \%$, exports decreased by $18.8 \%$ and imports by $17.8 \%$. Household final consumption expenditures had a very strong negative contribution to GDP growth, $-6.3 \%$, and the contribution of gross fixed capital formation was also strongly negative and amounted to $-3.4 \%$. In the neighboring countries that are not members of the European Union, and which published their data, there was a significant decline in the economy. Thus, in Northern Macedonia, the economic decline in the second quarter of this year was $12.7 \%$. Final household consumption fell by $9.9 \%$, while exports fell by a third, or $32 \%$, and imports by $30.2 \%$.
The percentages of decline in the second quarter are in some countries up to three times higher than the IMF estimate for the whole of 2020, which, if the situation does not improve significantly by the end of 2021, means that the final annual changes during this year's be significantly worse. ${ }^{1}$

\begin{tabular}{|c|c|c|c|}
\hline Država & 2019 & 2020 & 2021 \\
\hline Albanija & $2,20 \%$ & $\bigotimes, 50 \%$ & $6,10 \%$ \\
\hline BiH & $2,70 \%$ & $\$, 50 \%$ & $5,00 \%$ \\
\hline Bugarska & $3,40 \%$ & $\triangle 4,00 \%$ & $4,10 \%$ \\
\hline Hrvatska & $2,90 \%$ & $9,00 \%$ & $6,00 \%$ \\
\hline Mađarska & $4,90 \%$ & $\$, 10 \%$ & $3,90 \%$ \\
\hline CG & $3,60 \%$ & $\Delta 2.00 \%$ & $5,50 \%$ \\
\hline SQMakedonija & $3,50 \%$ & $\varangle 5,40 \%$ & $5,50 \%$ \\
\hline Poljska & $4,10 \%$ & $B, 50 \%$ & $4,60 \%$ \\
\hline Rumunija & $4,10 \%$ & $\triangle 4,80 \%$ & $4,60 \%$ \\
\hline Srbija & $4,20 \%$ & $2,50 \%$ & $5,50 \%$ \\
\hline Evrozona & $1,30 \%$ & $\$ 8,30 \%$ & $5,20 \%$ \\
\hline $\mathrm{CIE}$ & $2,10 \%$ & $\triangle 4,60 \%$ & $3,90 \%$ \\
\hline
\end{tabular}

Picture 1. Table GDP in 2020 and estimate for 2021.

Source: www.danas.rs/ekonomija/mmfbdp-bolji-nezaposlenost-problem/

For example, in Hungary, in the second quarter of 2020 , there was a decline of $14.5 \%$, and the IMF predicted a decline of $3.1 \%$ for the whole year. In Northern Macedonia, the decline in GDP in this quarter is $12.7 \%$, and the IMF predicted a decline of $4 \%$ in 2020. In Bulgaria, the quarterly decline is $10 \%$, and the annual projection of the IMF is a decline of $4 \%$.

The IMF has forecast an annual GDP decline of $9 \%$ for Montenegro, as well as Croatia, which fell by $14.9 \%$ in the second quarter of 2020. Croatia is somewhat less dependent on tourism than Montenegro, which is the most affected branch of the economy due to the corona virus epidemic.

\footnotetext{
${ }^{1}$ Obradović, M., www.danas.rs/ekonomija/mmfbdp-bolji-nezaposlenost-problem/
} 
The share of tourism in Croatia's GDP is $18 \%$, and in Montenegro it is $23 \%$. The decline in tourism revenues in Montenegro in the second quarter was $98 \%$, while in Croatia in this period the decline was as much as $80 \%$. In July and August, the decline in revenues from Montenegrin tourism is as much as $90 \%$, while in Croatia it is around $40 \%$. These data show that Montenegro will have a significantly higher percentage of economic decline than Croatia.

Representatives of the European Central Bank (ECB) point out that there can be no relaxation in the fight to recover from the economic consequences of the corona virus pandemic. In this regard, the ECB called on euro area governments to support fiscal spending. The ECB pointed out that, despite the recovery of the eurozone from the severe economic consequences of the quarantine measures introduced due to the pandemic, that recovery is uneven and uncertain, as several countries are fighting a renewed increase in new cases and a new wave of infection. In doing so, the ECB remains ready to adjust all its instruments to help the group of 19 countries that make up the eurozone overcome the current crisis.

A large number of shops in the central city zones throughout Serbia, which were looted years ago, are now empty. Thus, in the central city location in Belgrade, numerous catering facilities in the vicinity of Knez Mihailova are permanently or temporarily closed. The situation is similar in Nis, Novi Sad and the rest of Serbia. The closure of nightclubs, fast food restaurants, bakeries and kiosks is also evident, especially next to schools and colleges. Even the bars that were the most visited, now reject guests, because the working hours, according to the decisions of the Crisis Staff, are becoming more rigorous.

Many facilities are sold due to business difficulties, as well as due to high duties, fiscal and parafiscal levies. The number of these bills that regularly arrive at the address of the caterer is simply accumulating and there is no way to pay them. Because, many who have invested in the business of caterers are burdened with loans, while some have taken state aid and cannot reduce costs by simply sharing layoffs and laying off workers. They are looking for solutions to get out of the situation in sales or renting, because that is usually the only option. On the other hand, the demand for restaurants in service industries has stopped, because normally, no one decides to buy a restaurant in order to start a catering business in this period, because that would mean doing business in debt and with pronounced illiquidity. So the situation in these areas of business is such that many want to reorient themselves to other jobs and purposes that are more profitable in a pandemic. Thus, according to data from real estate sites, cafes in the center of Belgrade are sold at a price of about 200,000 euros. In centers outside Belgrade, shops are sold at prices of around 60,000 and 70,000 euros, and it is generally easier to sell smaller shops, which will be used for renting or other activities.

Among the most famous facilities advertised for sale is the restaurant "Srpska kafana", which is sold at a price of 750 thousand euros. 
In addition to the moratorium on loans, which could benefit, and to the greatest extent did, both companies and citizens, the state decided to include in the economic measures to support the economy and favorable special-purpose loans for liquidity and working capital, with an interest rate of $1 \%$, for which companies could apply by the end of 2020 . The grace period for their repayment is 12 months. Entrepreneurs, micro, small and medium-sized legal entities, but also agricultural farms and cooperatives, which perform production and service activities, were entitled to loans that could make their business a little easier.

From August 17, 2020, the registration of employers for the "My first salary" program began. Through that program, the salaries of newly employed young people are partly financed by the state, and they will start working in November. For those with a high school diploma, the state will give 20,000 dinars, and for young workers with a university degree, 24,000 dinars, for a period of nine months. This is for the first probationary period, the first year of their employment. Employers from the private and public sectors can apply for the program.

\section{WHAT IS PROFITABLE AND WHERE TO INVEST WHEN MANY BUSINESSES FAIL}

"Where, how and how much? These are the questions he asks himself each investor before investing in the future

Investment. The state with its regulations, measures and the control of their implementation is dictated by the business environment which are characterized by various factors. The business environment greatly affects the return on investment. If it is orderly and predictable, the investor can plan ahead the flow of your business. Otherwise, a messy business environment can be a big problem for economic development, for new investments and the development of society in general.

The quality of business organization is measured by different institutions local and international level. Some reference lists which are published annually are a good indicator what investors can expect when developing a business in some state. The most frequently mentioned lists are Doing business World Bank list, Index of Economic Freedom Heritage foundations, the Global Competitiveness Index of the World Economic Forum and Fraser's Economic Freedom of the World institute. Some countries are investing heavily and effortlessly would improve their position on these lists. The credibility of each The list depends on several factors, the number of countries involved observe, the quality of the information on which it is based ranking, sample size, coverage of the territory to which refers to research, etc. Our state is among the priorities. This Government envisages as one of the goals the improvement of Serbia's position on the World Bank's Doing Business list."2

"When it is uncertain both in life and at work, people usually strive for proven solutions and try to get back to the old way as soon as possible, playing it safe at least approximately that level. An unexpected blow to the crisis.

\footnotetext{
${ }^{2}$ Radovanović, J. Država kao partner u investiranju, Kako pametno investirati, Biznis i ljudi, God.1, br. 1 , str. 10
} 
Caused by a corona virus pandemic in this situation it suddenly set up almost the entire global economy. Most players look for safe solutions, some succeed, some do not, and one part is still different, seeking salvation and an opportunity for growth, where it is less common - to innovate.

In a country where the crisis is almost constant, innovation they are usually not an option for businessmen. Small and medium businesses are already in a big fight, trying to compensate for the dry period that occurred during the emergency conditions. In overcoming the negative consequences of the corona virus pandemic on business, entrepreneurs are there are several key dilemmas. Liquidity or profitability? Credit, borrowing? Loans through guarantee schemes, as well as funds from the Development Fund are maturity and price structured so that in the near future it is difficult to have more favorable conditions for obtaining new ones funds."

Renewable energy sources are a great development opportunity for Serbia, but also for all countries, especially underdeveloped ones, in order to ensure energy security and safety, both at the household level and at the level of each country (Stošić Mihajlović, Lj, 2017).

The justification for investing in renewable energy sources has long been known and proven by analysis. Also, solar panels in Serbia are not only the subject of discussion, but more and more is being invested in them; they can be seen on more and more buildings, houses and companies, and the reason is quite clear: savings on electricity bills. An additional incentive could be a new bill in the field of energy, which envisages the possibility and obligation to sell surplus energy to the state.

What primarily encouraged the installation of solar panels is the possibility of procuring solar technology under favorable conditions, because the technology itself has become easily accessible and economically justified. Thus, the price of installing solar panels and accompanying equipment has been reduced in recent years by as much as $90 \%$ compared to the period of 10 years ago. On the basis of cheaper and favorable procurement of equipment for the production of electricity from solar energy, the investment in the installation of solar systems pays off for the average household in seven to eight years.

In modern conditions, citizens are most attracted by the idea of saving in electricity consumption, ie the possibility of distributing all surplus energy in the electricity network of Serbia. With two solar panels installed on the roof of one household, a family can save more than $15 \%$ of monthly electricity consumption. Normally, a larger number of panels also increases the percentage of savings on the electricity bill that can be used to perform daily maternity activities, for heating and cooling the house.

The first thing interested citizens need to know is how many kilowatt-hours of electricity they consume per month. Based on that, citizens can further calculate how many solar panels they would need to cover primarily the needs of their household.

\footnotetext{
${ }^{3}$ Milosavljević, I., Kako pametno investirati u krizi? Biznis i ljudi, God.1, br.1, str.20
} 
For example, if the average household consumes about 600 kilowatt-hours of electricity per month, with 2 kilowatts of solar panels they can produce 200-250 kilowatt hours, and could reduce the consumption of electricity they take from the electricity network by that much.

According to current prices, such a system for two kilowatts is a system without batteries and cost around 3,000 euros. Even smaller investments are possible. Thus, it is possible to install a solar panel of 1 kilowatt, which costs about 1,600 euros, all at current prices. However, it should always be borne in mind that the price of equipment and technology for the production of electricity with the help of solar panels is falling every day, as scientific and applied research in this area is intensifying.

Solar panels can be immediately installed on the roofs of houses, factories or to make a field of solar panels in those areas that are not suitable for any other activity. For apartments individually, in current residential buildings, that is still not possible.

As already mentioned, for one house, this investment can be repaid in seven to eight years, which is the average repayment time of investments in our country. The method of return is direct - through savings, which is a better way and even more convenient than keeping money in the bank.

Namely, according to the current interest rates, the price of depositing money in a bank, the interest rate is $1-2 \%$ annually, and if you invest in solar panels, the rate of return is over $10 \%$ of the investment. Of course, we are talking here about the return on investment in relation to the current price of electricity, and it is clear that electricity will certainly be more expensive. In addition, there are no carbon dioxide emissions in this activity, nor is there an obligation to reduce those emissions.

Also, companies are more and more interested, so that many already have builtin solar systems, while others are constantly interested, so that the interest is growing every day. It pays more for companies because the price per kilowatt is lower compared to households. In addition, the economy has the opportunity to return the invested VAT for its investments, so then it is even more profitable.

In Serbia, the interest in installing solar systems is growing from year to year. In previous years, it was mostly investors interested in experimenting with this energy, while now it is increasingly interesting for households, especially those that have higher electricity consumption in summer - due to the use of air conditioning and winter heating.

The new law on energy efficiency, whose adoption is expected soon, will surely make a "boom" in the application of solar panels, according to experts in the Serbian Chamber of Commerce (SCC). Precisely, PKS should keep a register of energy service providers, so that the new law would enable small private owners of solar panels to sell their surplus electricity to EPS, which will introduce significant changes in the market. Also, the formation of associations, i.e. cooperatives, will probably be allowed, in order for small producers to be organized in a certain way.

During the period of the day when there is no electricity consumption, for example when no one is at home, then that electricity is returned to the network made by their mini power plant, and that is the part of energy that could be used for sale. 
Legislative government regulations are now underway in Serbia, when it will be possible to see in more detail how much individuals will be able to charge per kilowatt hour of energy, ie whether they will only be able to reduce a kilowatt hour by a kilowatt hour or have a certain fee for that.

\section{ADDITIONAL EFFECTS ON} ENVIRONMENTAL PROTECTION USING SOLAR PANELS FOR THE PURPOSE OF ELECTRICITY PRODUCTION

Man today uses solar energy in various ways, and the reasons for its increasing use are primarily in the fact that people have recognized the many benefits, from saving money to protecting the environment and air from major pollution.

The most common form of human use of solar energy is photovoltaic solar panels that absorb sunlight to generate electricity. They can be used in households as primary or secondary sources of electricity. Water heating, especially in closed tanks and pools, or operation of small devices, i.e. machines that are valid for small consumers, are just some of the examples of smart exploitation of solar energy.

That's not all - it is also possible to make large-scale plants from photovoltaic panels whose purpose is to supply more residential or commercial buildings with electricity. This can be seen as an adequate response to the challenges posed by the fourth industrial revolution.

Due to all of the above, the popularity of this form of renewable energy and its application is growing.
Outdoor solar lighting is one of the easiest ways to improve energy efficiency in lighting the exterior of households and business facilities. Solar lamps have a large capacity battery in which they store electricity obtained from the sun. Powerful crystalline solar cells convert sunlight into electricity, and at night the lights are automatically turned on via sensors.

The increasingly popular and practical use of solar energy includes heating with the help of solar collectors. Solar collectors absorb the heat of solar radiation and transfer it to the water in the solar tank. Longevity is considered to be their main advantage, in addition they have a very high performance and are easy to install. In this way, unlimited amounts of free energy are used, the consumption of fossil fuels and environmental pollution are reduced. Namely, there is no carbon dioxide emission during the operation of solar collectors.

The principle according to which heating is realized is simple. Solar collectors use sunlight and convert it into heat. With the help of a pump, a special transfer fluid is forced into the heat exchanger of the tank, so the thermal energy is transferred to the water. This technology can also be used to cool water at night (usually only necessary in tropical climates).

When it comes to pool heating, solar absorbers are used. They are easily and without much investment provided with a satisfactory temperature in the pools during the summer and the transition period. In outdoor pools, solar absorbers increase the water temperature by 3 to 8 degrees. 
A slightly larger investment is the installation of a stainless steel solar water heater, i.e. connecting this element to a solar collector system. However, since this can provide significant energy savings for water heating, the investment pays off in the long run.

Solar energy is already a reliable backup source of energy when it comes to powering devices and electronics, however, it can also serve as a primary. There are solar chargers that can supply energy to a wide variety of devices - from a mobile phone, through tablets to music speakers and electronic readers. In addition, there are solar air conditioners, various thermostats, but also mini refrigerators and freezers.

More and more people are adopting the use of solar products and are realizing the importance of this renewable energy source. Therefore, it is quite expected that over time, the awareness of how we consume energy will change, that is, we will charge the devices that are in everyday use. $^{4}$

Solar panels reduce monthly electricity bills and contribute to a cleaner and healthier environment

There are two reasons why households or companies choose to install solar photovoltaic panels on the roofs of houses or companies. The first is economic because this investment will reduce their monthly electricity bills, provide companies with additional competitiveness and efficiency in business, and the second is increasingly environmentally friendly and the desire of both individuals and the business sector to contribute to a cleaner and healthier environment through renewable energy production.

With fewer hours of sunshine, Germany has almost $50 \mathrm{GW}$ of installed power in the solar system, and Serbia about $10 \mathrm{MW}$, which is five thousand times more. In most parts of Serbia, the number of hours of solar radiation is significantly higher than in many European countries. Thus, in Germany, about 1,000 kilowatt-hours $(\mathrm{kWh})$ are produced per installed kilowatt $(\mathrm{kW})$ of solar panels, and in Serbia 1,200$1,400 \mathrm{kWh}$. However, even with a smaller number of sunny hours, Germany has almost $50 \mathrm{GW}$ of installed power in the solar system, and Serbia about $10 \mathrm{MW}$, which is even five thousand times more!

Although Serbia does not have regulations that would regulate the status of software and encourage their development, things are still moving forward, so hundreds of solar photovoltaic power plants have been installed, which provide green electricity to citizens and companies.

\footnotetext{
${ }^{4}$ samoobrazovanje.rs/najcesci-nacini-primenesolarne-energije-danas/
} 


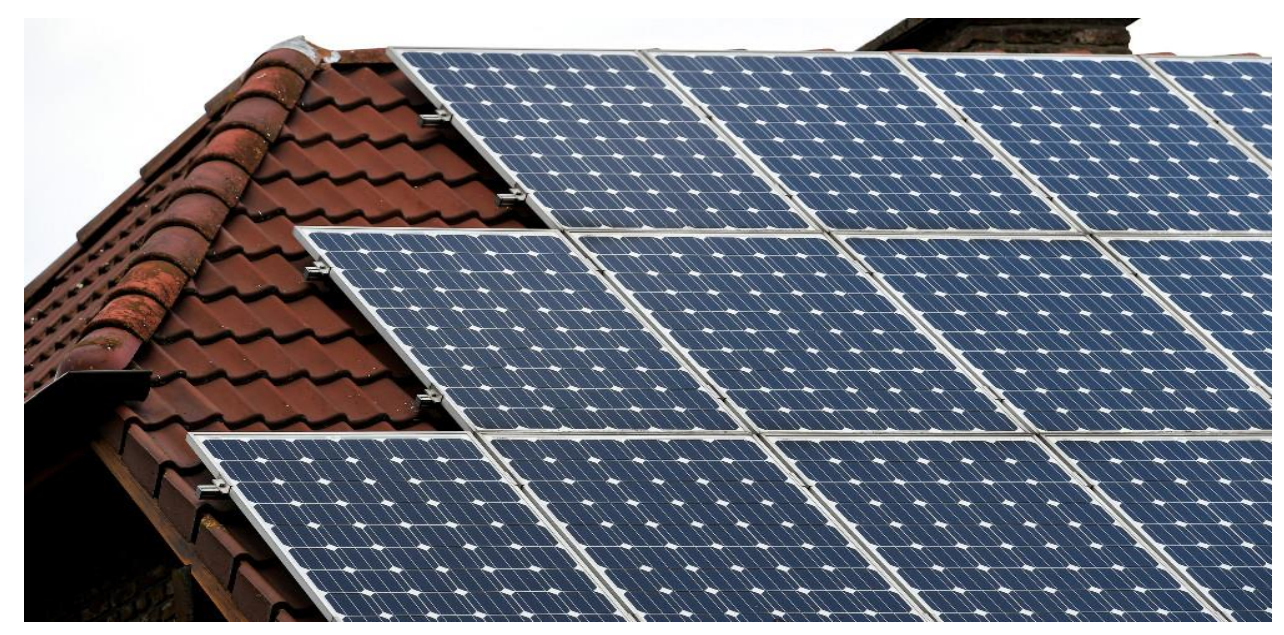

Picture 2. Installed solar panels on the roof of the building

In the area of modern economy and environmental protection there are no significant changes: the old problems are not solved, and the existing ones are deepening. Humanity is still struggling with three existential problems: lack of food, lack of drinking water and insufficiently energized energy. They are also associated with the dangers of further degradation of the environment, the general fear and fear of terrorism and wars, the emergence of diseases for which modern medicine simply has no solution and which threatens to overcome the challenge of pandemic. Energy is still a mood of economic development, with at the same time a disastrous effect on the environment, when traditional sources of fossil resources are used as sources of energy. The paper explores the phenomenon of the impact of energy on the sustainable development of the economy, with a key focus on environmental protection, as well as the possibilities for adaptation to mitigate the consequences of this global phenomenon. In this regard, special attention has been devoted to researching the role and significance of energy from renewable sources as a possible response to current or expected climate stimuli or their consequences in natural and humanism systems.

Particular emphasis is placed on the principle of adaptation, which includes mitigation of damages or the exploitation of effective opportunities; understanding how climate can change, what can be impacts, and capacity building and action on these impacts. ${ }^{5}$

The first wave of COVID-19 led to a "lock", i.e. almost all economic activity stopped. In a situation when air transport was completely stopped, when traffic was stopped due to the imposed curfew in many countries of the world, it proved to be a good effect on the environment. Namely, the pollution above the planet Earth was significantly reduced. In that sense, environmentalists now.

\footnotetext{
${ }^{5}$ Stošić-Mihajlović, L., \& Trajković, S. [2018]. The importance of energy for the economy, sustainable development and environmental protection: An economic aspect. Journal of Process Management. New Technologies , 6(1), 20-26.
} 
They are increasingly suggesting that a global lockdown (lockdown) is needed every two years in order to meet the goals of the Paris Climate Agreement. If carbon dioxide emissions do not fall to the extent recorded during the global lockdown (lockdown) approximately every two years for the next decade, the Earth will warm to apocalyptic levels.

So the explanation is that such a decline over a decade would be needed to curb global warming. This only confirms the view that climate change cannot be a side issue and must be at the heart of every government. In that sense, it is important to point out that every strategy, every plan, every government must be in line with the fight against climate change.

Some strategic actions that could be retained as some of the benefits of the pandemic have already been implemented and in many cases have been implemented for years: from planned cities, to encouraging "active transport" (walking and cycling) and the use of public transport, to promoting teleworking where it was possible, which is certainly small and not enough, but can be a significant incentive for further engagement in reducing global halogen pollution.

All types of renewable energy (hydropower, geothermal energy, biomass energy, solar and wind energy) are inseparable and therefore need to be used to the maximum, on the one hand, because they are renewable, and on the other hand, it is energy that does not generate waste, does not create pollution does not create problems related to clean air, clean environment and clean water, and does not affect sustainable development.
In the first place, it is necessary for countries to stop using fossil fuels, to undertake structural changes, in order to switch to renewable energy sources.

In fact, last year, the World Economic Forum published criticism of what the locks did to the cities - turned them into unbearable baskets of snitches in which even the theater can no longer be visited. But the World Economic Forum also released a video praising the silence and cleaner air - and the lack of people.

\section{CONCLUSION}

The pandemic of the COVID-19 virus leaves devastating consequences everywhere and in every place - in addition to illness and death, there is also a blow to the country's economy.

Our planet is definitely not immune to crises on society as a whole. From the Great Depression, through the global economic crisis of 2008, to the situation we are in today - have we learned anything like civilization, and is there a "proven recipe" for resisting economic downturns? According to statistics, about $20 \%$ of new businesses fail during the first two years; $45 \%$ in the first 5 years, and $65 \%$ of "new jobs" fail after 10 years, even though they have already achieved some life cycle by then. Only $1 / 4$ survives 15 years, and even longer. The question is, what is smart to invest in?

Judging by the current situation, the food and beverage businesses are less likely to "fail", while tourism and catering have failed because they are not on the priority list. 
These two sectors, along with air transport, are currently the most endangered, and immediately behind them is the sales sector, in the domain of things that we do not need. On the other hand, what will not "stop" in a crisis of this kind are jobs that deal with the production or sale of clothes and equipment for babies and children, because they are also considered necessary. The analysis showed that it is profitable to invest in equipment for the production of "green" electricity, ie energy from renewable energy sources, specifically solar energy.

\section{REFERENCES}

1. Eurostat, ec.europa.eu/eurostat/en/web/productseurostat-news/-/ddn-20210303-1
2. European Central Bank, 2021. www.ecb.europa.eu/pub/economicbulletin/html/eb202008.en.html

3. Milosavljević, I., Kako pametno investirati u krizi? Biznis i ljudi, God.1, br.1, str.20

4. Obradović, M., MMF: BDP bolji, nezaposlenost problem, oktobar 2020. www.danas.rs/ekonomija/mmf-bdp-boljinezaposlenost-problem/

5. Radovanović, J. Država kao partner u investiranju, Kako pametno investirati, Biznis i ljudi, God.1, br.1, str.10

6. Stošić-Mihajlović, L., \& Trajković, S. [2018]. The importance of energy for the economy, sustainable development and environmental protection: An economic aspect. Journal of Process Management. New Technologies , 6(1), 20-26.

7. Stošić Mihajlović, Lj., [2017]. Obnovljivi izvori energije, VŠPSS, Vranje, str. 82

8. https://samoobrazovanje.rs/najcescinacini-primene-solarne-energije-danas/ 